\title{
Switched Inductor Quasi-Z-Source Based Back-to-Back Converter for Variable Speed Wind Turbines with PMSG
}

\author{
L. Bisenieks, D. Vinnikov, S. Ott \\ Department of Electrical Drives and Power Electronics, Tallinn University of Technology, \\ Ehitajate str. 5, 19086 Tallinn, Estonia, phone:+372620 3548,e-mail: lauris.bisenieks@rtu.lv \\ crossref http://dx.doi.org/10.5755/j01.eee.114.8.698
}

\section{Introduction}

Sustainability is the main aspect that forces the renewable energy sources to be implemented for electric energy generation instead of fossil ones. Wind energy is quite attractive among other sources because of its commercial potential ( $72 \mathrm{TW})$ that is five times higher than world energy demand in all forms [1]. However, the installed capacity in 2009 was only $159 \mathrm{GW}$ [2]. Large turbines dominate the market, but there is also a demand for small turbines in the power range up to $15 \mathrm{~kW}$ as the power source for micro generators.

A micro generator is an electrical energy source that includes all interface units and operates in parallel with the distribution network. Some energy sources can be connected directly to the distribution network, but in the case of DC power sources or variable speed wind turbine (VSWT) systems it is necessary to use a power converter that interfaces the source and the grid.

Generally, VSWT based micro generators consist of a wind turbine, a generator and an interface converter (Fig. 1). Wind turbines capture wind energy and convert it to rotational mechanical energy. Variable speed operation of the wind turbine allows extraction of higher energy from wind than constant speed systems [3]. The generator converts mechanical energy into electricity. Different types of generators can be used in wind energy conversion systems (WECS), but permanent magnet synchronous generators (PMSG) dominate the market. The main advantage of PMSG is the possibility of multipole design that offers slow speed operation and the possibility of gearless WECS construction. Another advantage is maintenance free operation since there are no brushes. The main drawback of PMSG is the dependence of its output voltage on the rotation speed. The difference between the minimum and the maximum voltage can reach four times in VSWT applications [2]. This drawback can be easily overcome with the help of an appropriate interface converter.
The interface converter rectifies the input $\mathrm{AC}$ with variable voltage and frequency, adjusts voltage levels and inverts DC voltage into AC with grid voltage and frequency. Additionally, it should have maximum power point tracking (MPPT) functionality to extract more power from wind. Different topologies of the interfacing converter are discussed in the literature [3-8]. Basically, they can be categorized as topologies with HF isolation (Fig. 1a) [2] and [4] and those without isolation (Fig. 1b) [5-8]. This paper is devoted to the transformerless topologies, i.e. topologies without isolation.

Most of the topologies without isolation have an intermediate DC link. It means that on the generator side there is a rectifier, but an inverter is placed on the grid side. Some low pass filter can be added to the inverter to fulfill standard requirements. The overall performance of an interface converter is highly affected by the properties of the combination of the generator side and grid side converter.

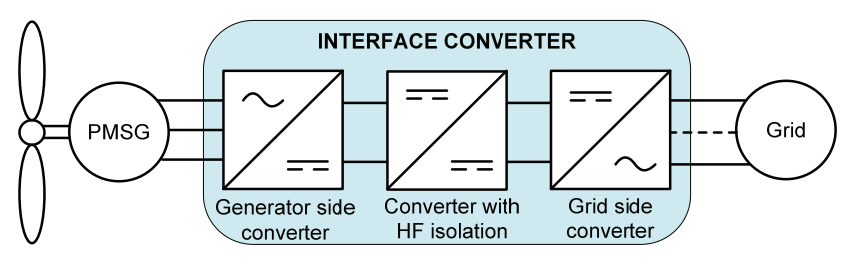

a)

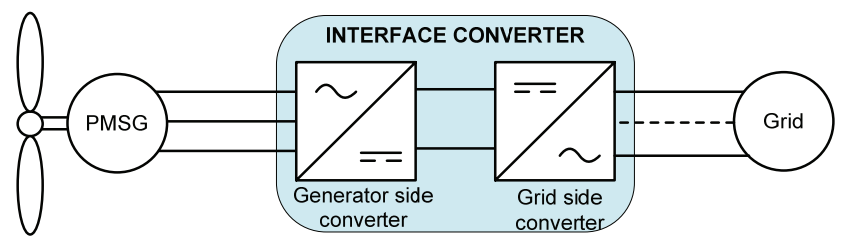

b)

Fig. 1. Generalized block diagrams of interface converters for VSWT with PMSG: with high-frequency isolation (a) and without isolation (b) 


\section{State of the art topologies and issues}

One of the simplest transformerless interface converter topologies consists of uncontrolled rectifier and grid side converter (Fig. 2a). This topology is the cheapest solution due to low number of controlled switches and simple control system which is necessary only for the grid side inverter. The main disadvantage of this solution is the absence of DC link voltage regulation possibility that leads to lack of extracted power at low speeds [5]. Additionally, this topology does not offer any generator power and speed control possibilities that exclude MPPT functionality. All these disadvantages make this topology unsuitable for VSWT applications.

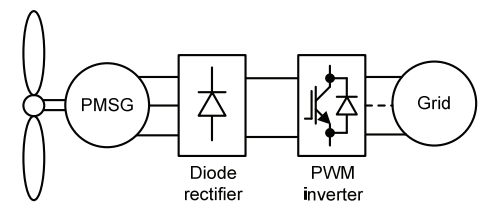

a)

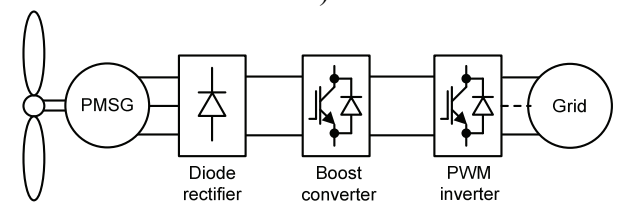

b)

Fig. 2. Interface converter with a diode rectifier (a) and improved solution with an additional boost converter (b)

The topology with an additional boost converter (Fig. 2b) was introduced to improve the generator power control capability by keeping the power circuit of the converter at a simple level [3]. This topology offers a possibility to extract power at low wind speeds and thus significantly expand the operation range of the PMSG based VSWT system. These improvements are significant, but due to the limited PFC capability and lower efficiency than with a controlled rectifier, it is not feasible to use the topology with a boost converter in high efficiency applications [5].

The back-to-back converter (Fig. $3 a$ ) has high control flexibility of a generator torque and current [6]. Implementation of the controlled rectifier allows the generator to operate with the unity power factor and easily implement MPPT functionality. The energy storage devices like batteries (Fig. $3 b$ ) can be added to the intermediate DC link of the back-to-back converter to improve the low voltage ride-through (LVRT) capability. The LVRT capability becomes more and more important in the context of grid code requirements [8]. The main disadvantage of the classical back-to-back converter is only two voltage regulation freedoms of the generator and grid side converters. The generator side converter can boost the generator voltage to obtain the necessary level of the DC link voltage, but the inverter can only reduce it.

Since the VSWT operates at low rotation speeds more than half a time [2] and the output voltage of the generator is significantly lower than the nominal at this mode, the boost properties of the interface converter become an issue. This is especially topical at micro power level, where the nominal generator voltage is lower than the grid voltage.

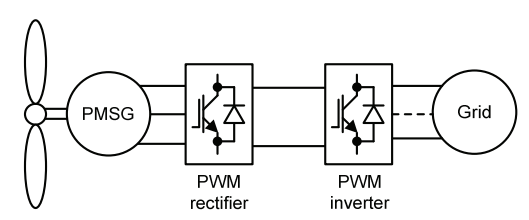

a)

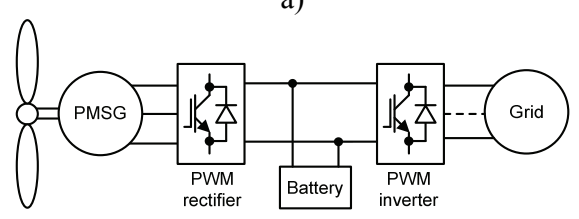

b)

Fig. 3. Traditional back-to-back interface converter (a) and backto-back interface converter with auxiliary battery for energy storage (b)

Implementation of Z-source inverters (ZSI) has become popular in recent years in applications where additional voltage boost is necessary [6]. The ZSI topology features the PWM inverter coupled with a symmetrical lattice network consisting of two inductors and two capacitors connected in X-shape (Fig. 4a). The ZSI has inherent voltage boost and buck capability using the shootthrough switching states in each phase leg of the PWM inverter. This enables the proposed wind generation system to achieve the demanded variable-speed operation.

The utilization of quasi-Z-source (qZS) network in the interface converter (Fig. $4 b$ ) in addition to the benefits of the Z-source based converter offers continuous input current of the qZS-network as well as reduced DC voltage of the capacitor $C_{2}$ [7].

In contrast to the traditional back-to-back topology both Z-source network based back-to-back interface converters have three voltage regulation freedoms: the generator side converter can boost the generator voltage to obtain required level of the DC link voltage, and the gridside inverter can perform both the voltage boost and buck functions.

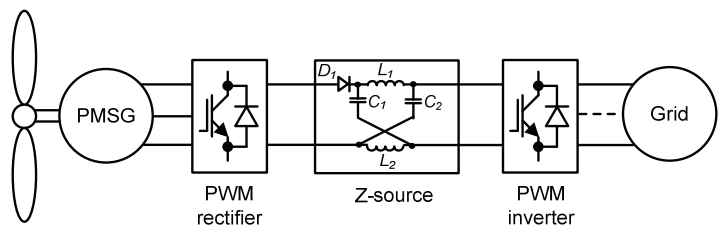

a)

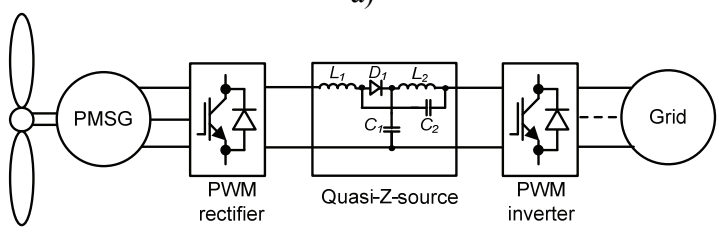

b)

Fig. 4. Z-source network based back-to-back interface converters: topology with Z-source (a) and topology with quasi-Z-source (b)

This paper proposes a possibility for further improvement of the quasi-Z-source based back-to-back interface converter by the introduction of the switched inductor quasi-Z-source network (Fig. 5). In contrast to converters presented in Fig. 4 the new topology offers the increased voltage boost capability of the grid-side inverter. 


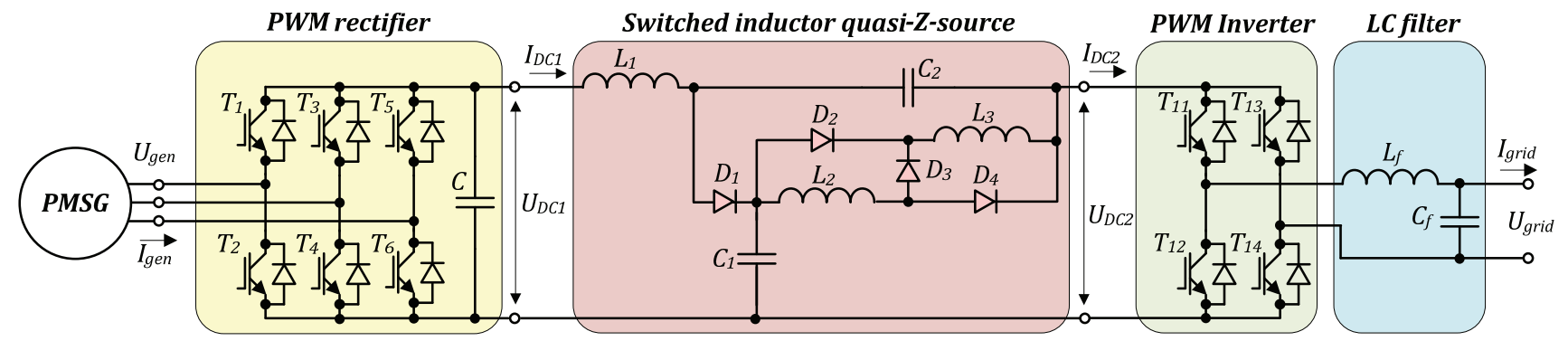

Fig. 5. New proposed switched inductor quasi-Z-source based back-to-back converter for VSWTs with PMSG

Operation principle of a switched inductor quasi-Zsource inverter

As stated above, this paper proposes the switching inductor (SL) technique to be implemented in the traditional qZSI to improve its voltage boost properties. The second inductor $L_{2}$ in The qZS-network (Fig. $4 b$ ) was replaced by switched inductors, as shown in Fig. 5.

The proposed SL qZS network consists of three inductors $\left(L_{1} \ldots L_{3}\right)$, four diodes $\left(D_{1} \ldots D_{4}\right)$ and two capacitors $\left(C_{1}\right.$ and $\left.C_{2}\right)$. Inductors $L_{2}$ and $L_{3}$ can be implemented as coupled inductors. Coupled with the grid side PWM inverter, the SL qZS network forms the SL quasi-Z-source inverter (SL qZSI). Similarly to the traditional qZSI [9], the SL qZSI has two main types of operational states at the DC side: non-shoot-through states and shoot-through states. Let us assume that the operating period $T$ of the SL qZSI consists of a shoot-through state $t_{S}$ and an active state $t_{A}$

$$
\frac{t_{A}}{T}+\frac{t_{S}}{T}=D_{A}+D_{S}=1
$$

where $D_{A}$ and $D_{S}$ are the duty cycles of an active and shoot-through states, correspondingly.

In order to simplify the analysis it was assumed that the capacitors, inductors and diodes of the SL qZS network are lossless. Fig. 6 shows the equivalent circuits of the SL qZSI operating in the CCM for the shoot-through (a) and active (b) states.

At the steady state the average voltage of the inductors over one operating period is zero:

$$
\left\{\begin{array}{l}
U_{L 1}=\int_{t}^{t+T} u_{L 1} d t=0, \\
U_{L 2}=\int_{t}^{t+T} u_{L 2} d t=0, \\
U_{L 3}=\int_{t}^{t+T} u_{L 3} d t=0 .
\end{array}\right.
$$

Based on that fact and defining the shoot-through duty cycle as $D_{S}$ and the non-shoot-through duty cycle as $\left(1-D_{S}\right)$, the inductors voltages over one operating period could be represented as:

$\left\{\begin{array}{l}U_{L 1}=\bar{u}_{L 1}=D_{S}\left(U_{D C 1}+U_{C 2}\right)+\left(1-D_{S}\right)\left(U_{D C 1}-U_{C 1}\right)=0, \\ U_{L 2}=U_{L 3}=\bar{u}_{L 2}=\bar{u}_{L 3}=D_{S} U_{C 1}+\left(1-D_{S}\right)\left(-\frac{U_{C 2}}{2}\right)=0 .\end{array}\right.$
Equations for average capacitor voltages $U_{C l}(4), U_{C 2}(5)$ and peak inverter input voltage $U_{D C 2}(6)$ are derived from the steady state analysis:

$$
\begin{gathered}
U_{C 1}=\frac{U_{D C 1} \cdot\left(1-D_{S}\right)}{\left(1-2 \cdot D_{S}-D_{S}^{2}\right)}, \\
U_{C 2}=\frac{U_{D C 1} \cdot 2 \cdot D_{S}}{\left(1-2 \cdot D_{S}-D_{S}^{2}\right)}, \\
\hat{U}_{D C 2}=\frac{U_{D C 1} \cdot\left(1+D_{S}\right)}{\left(1-2 \cdot D_{S}-D_{S}^{2}\right)}=B \cdot U_{D C 1} .
\end{gathered}
$$

The voltage conversion ratio $G$ of the whole inverter can be expressed by

$$
G=\frac{U_{g r i d m}}{U_{D C 1}}=M \cdot B,
$$

where $M$ is the modulation index. The modulation index is connected with the shoot-through duty cycle by the following relation [7]

$$
M \leq 1-D_{S} .
$$

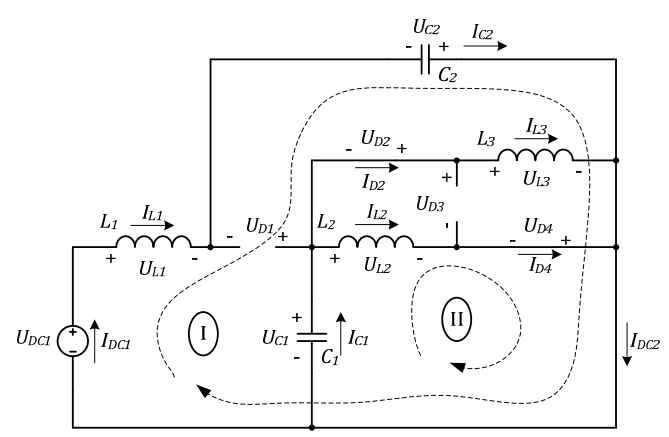

a)

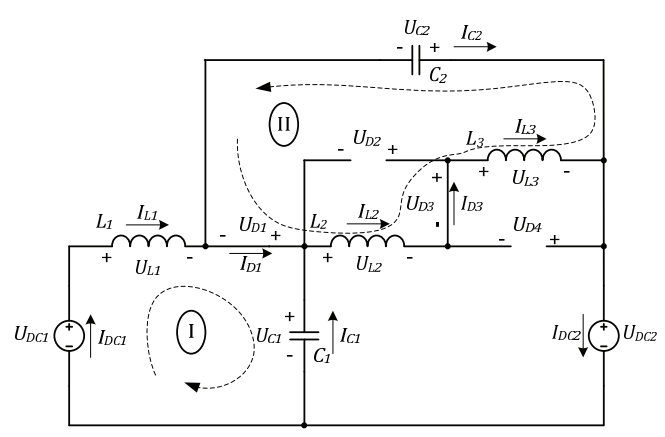

b)

Fig. 6. Equivalent circuits of the SL qZSI: during shoot-through state (a) and during active (non-shoot-through) state (b) 
In Fig. 7 the voltage boost factor $B$ and the voltage conversion ratio $G$ of the traditional qZSI are compared with those of the proposed SL qZSI. It is seen that the shoot-through duty cycle $D_{S}$ for the SL qZSI is lower than for traditional qZSI at the same voltage conversion ratio $G$ (Fig. 7b). This is significant feature of the SL qZSI that allows expand the grid voltage regulation possibilities at reduced grid side DC link peak voltage $U_{D C 2 p}$.

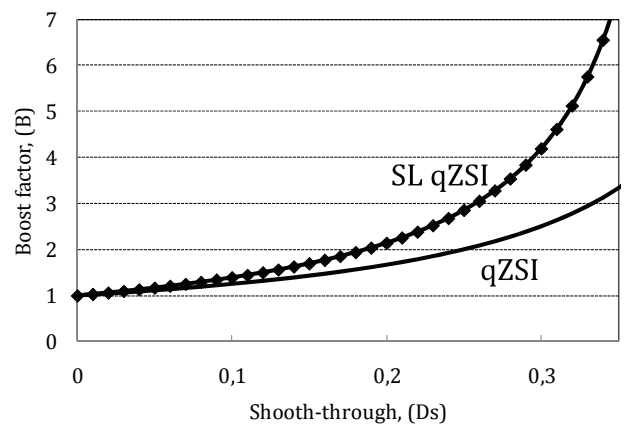

a)

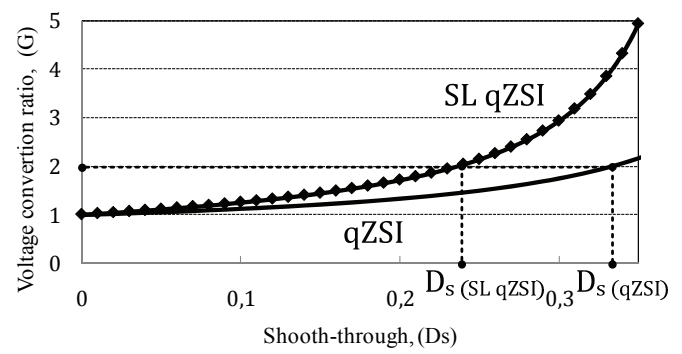

b)

Fig. 7. Boost factor B (a) and voltage conversion ratio $G(b)$ as functions of the shoot-through duty cycle for qZSI andd SL qZSI

\section{New proposed back-to-back interface converter}

This section unveils the operation principle of the new proposed interface converter (Fig. 5) in residential PMSG based wind turbines with power rating up to $15 \mathrm{~kW}$.

Operation modes of the interface converter. Generally, PMSG based VSWTs have three distinct operation modes: silent mode, variable speed operation mode and constant speed mode. A turbine is silent in two cases: wind speed is below a cut-in level or above the cutoff speed. Turbines operate at variable speed in the wind velocity range from cut-in to rated wind speed. Rated wind speed differs by turbine types, but often has the value of 12 meters per second. Constant speed mode takes place above the rated wind speed and output power of the turbine remains constant at this mode.

PMSG with 8 pole pairs was considered as a power source in this research. Its line voltage is $140 \mathrm{~V}$ at $375 \mathrm{rpm}$, but it can operate up to $510 \mathrm{rpm}$. This speed is considered as the maximum power operational point for the turbine and the generator. Generator power reaches $1250 \mathrm{~W}$ at this point with the output voltage of $183 \mathrm{~V}$. Cutin speed for a turbine is $125 \mathrm{rpm}$ and it can produce $40 \mathrm{~W}$, but the generator voltage is only $48 \mathrm{~V}$ at this point. So this is the lowest input voltage for an interface converter.

Based on the specifications of the PMSG the operation modes of the proposed back-to-back interface converter are presented in Fig. 8. The necessary voltage boost is obtained in two steps. The PWM rectifier stabilizes the DC link voltage $U_{D C I}$ to a $150 \mathrm{~V}$ level when the generator voltage is below $112 \mathrm{~V}$. This operation mode of the converter is called a PWM mode. The transferred power of the converter lies between $40 \mathrm{~W}$ and $330 \mathrm{~W}$ at this mode.

The controlled rectifier works as diode rectifier when the generator voltage $U_{\text {gen }}$ is above $112 \mathrm{~V}$. In this mode the DC link voltage is changed proportionally to the generator voltage, at the range from $150 \mathrm{~V}$ in rated generator speed conditions up to $250 \mathrm{~V}$ at the maximal speed.

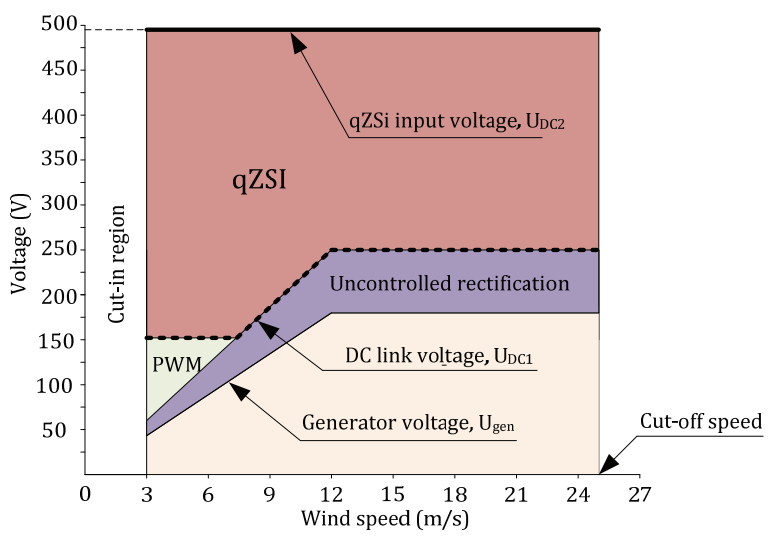

Fig. 8. Operation modes of the proposed converter

The SL qZS network with appropriate inverter control is stabilizing the peak value of the inverter side DC link voltage $U_{D C 2}$ to $490 \mathrm{~V}$ despite the voltage variations on the generator side DC link. The inverter input voltage $U_{D C 2}$ regulation is obtained by changing the shoot-through duty cycle $D s$ [9]. The peak value of the inverter side DC link voltage $U_{D C 2}$ is so high due to lower modulation index $M$ if compared with voltage source inverters. Modulation index is limited by shoot-through states implemented in SL qZSI.

The variation range of the voltage conversion ratio $G$ (Eq. 7) lies between 1.44 and 2.4 that corresponds to the generator side DC link voltage $U_{D C I}$ range from $250 \mathrm{~V}$ up to $150 \mathrm{~V}$. Since the modulation index $M$ and the boost factor $B$ are the functions of $D_{S}$, the appropriate values of shoot-through can be found for minimum and maximum $G$ values. The variation range of the shoot-through duty cycle $D_{S}$ is from 0.17 in maximum speed conditions to 0.27 in the cut-in speed conditions.

Analysis of simulation and experimental results. A series of simulations and experiments were performed to verify the proper operation of the proposed SL qZSI based back-to-back converter. Tests were performed at three characteristic operation points of the VSWT system to demonstrate the converters operation modes in the entire generator voltage and power range [2]. These points are: cut-in speed (low voltage and minimum power), rated speed (corresponds to $7.5 \mathrm{~m} / \mathrm{s}$ wind speed) and maximum generator speed, power conditions. General parameters of experimental setup based on 1.3 kW PMSG and proposed interface converter are summarized in Table 1 . The simple boost control technique [7] was implemented for the SL qZSI during simulations and tests. The operating frequency 
of the SL qZSI network was $20 \mathrm{kHz}$ and maximal switching frequency of transistors $-40 \mathrm{kHz}$.

Table 1. General specifications of experimental setup

\begin{tabular}{|c|c|}
\hline Component & Value or type \\
\hline \multicolumn{2}{|r|}{$P M S G$} \\
\hline Phase resistance & $1 \Omega$ \\
\hline Phase inductance & $5 \mathrm{mH}$ \\
\hline \multicolumn{2}{|r|}{ Interface converter } \\
\hline$T_{1} \ldots T_{6}$ & $600 \mathrm{~V} / 48$ A IGBT (IXSH24N60AU1) \\
\hline$T_{11} \ldots T_{14}$ & $600 \mathrm{~V} / 12$ A IGBT (G4PC30UD) \\
\hline$D_{1} \ldots D_{4}$ & $600 \mathrm{~V} / 120 \mathrm{~A}$ fast diode (STTH200L06TV) \\
\hline Capacitance of $C$ & $470 \mathrm{uF}$ \\
\hline Inductance of $L_{1} \ldots L_{3}$ & $1.2 \mathrm{mH}$ \\
\hline Capacitance of $C_{1} \ldots C_{2}$ & $180 \mathrm{uF}$ \\
\hline Inductance of $L_{f}$ & $100 \mathrm{uH}$ \\
\hline Capacitance of $C_{f}$ & $2 \mathrm{uF}$ \\
\hline
\end{tabular}

The tests were performed in two stages. First, the operation of PWM rectifier was studied, which is followed by the validation of the SL qZSI.

Analysis of experimental results of PWM rectifier. Experiments with PWM rectifier were performed in order to ensure that there is no need for additional inductors between PMSG and rectifier for proper boost functionality. First test was performed at generator voltage $U_{\text {gen }}=53 \mathrm{~V}$ and $40 \mathrm{~W}$ load, which corresponds to the cut-in speed conditions. Simple boost control was realized by controlling only three lower transistors with the fixed duty cycle at $10 \mathrm{kHz}$ switching frequency. Generator current $I_{\text {gen }}$ (Fig. 9a) is not sinusoidal due to simple boost control, but the amplitude of the generator voltage $U_{g e n}$ appears as $150 \mathrm{~V}$, since this is modulated signal with amplitude equal to DC link voltage $U_{D C l}$ (Fig. $9 b$ ).

Second test was performed at rated speed conditions, when generator speed is $315 \mathrm{rpm}$ and its power reaches $330 \mathrm{~W}$. The amplitude value of generator voltage $U_{g e n}$ reaches $150 \mathrm{~V}$ and there is no need for the boost (Fig. 10).

Third test was performed at maximal speed and power of the PMSG: $510 \mathrm{rpm}$ and $1250 \mathrm{~W}$, respectively (Fig. 11). Since the nominal speed of generator is $375 \mathrm{rpm}$, the test was necessary to verify the generator ability to produce required power at this speed. The amplitude value of generator output voltage reaches $250 \mathrm{~V}$ at this point and is maximal input voltage for the SL qZSI.

After the experiments it was concluded that the PWM rectifier operates as expected thus ensuring the demanded voltage on the generator side DC link within the whole operation voltage range of the selected PMSG.

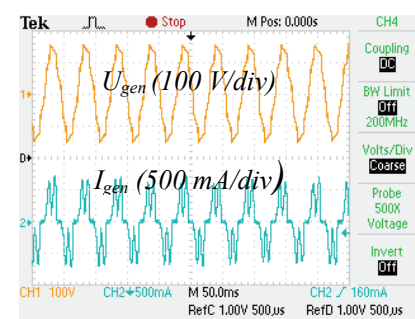

a)

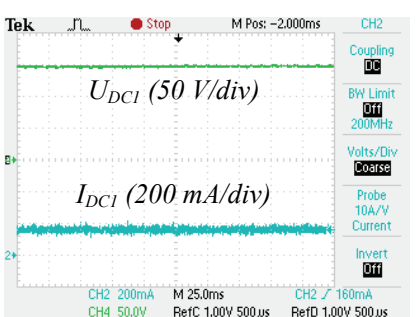

b)
Fig. 9. PMSG voltage and current (a) and generator side DC link voltage and current (b) at $40 \mathrm{~W}$

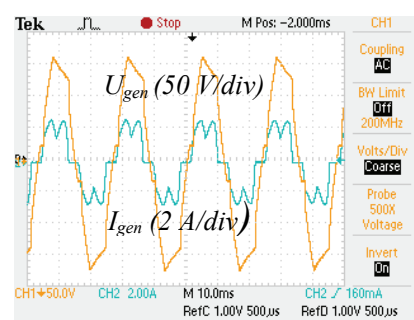

a)

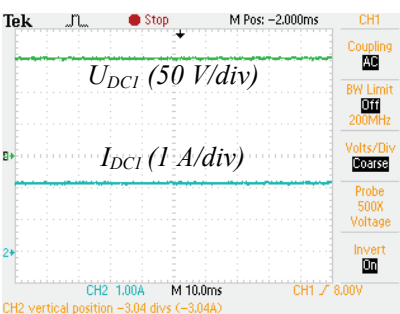

b)
Fig. 10. PMSG voltage and current (a) and generator side DC link voltage and current (b) at $330 \mathrm{~W}$

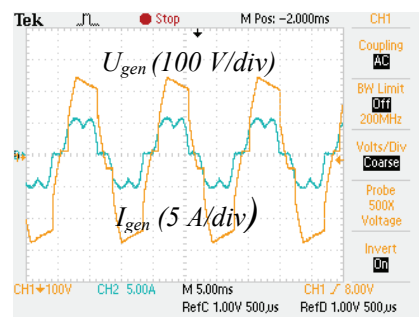

a)

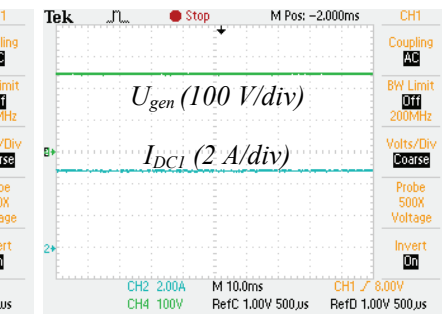

b)
Fig. 11. PMSG voltage and current (a) and generator side DC link voltage and current (b) at $1250 \mathrm{~W}$

Analysis of simulation and experimental results of the $S L$ qZSI. First simulations and tests were performed at the generator side DC link voltage of $150 \mathrm{~V}$. The power rating was $330 \mathrm{~W}$. To boost this voltage to the desired level of the intermediate DC link $\left(U_{D C 2}=490 \mathrm{~V}_{\text {peak }}\right)$ the shoot-through duty cycle $D_{S}$ was set to 0.27 . Fig. $12 a$ shows that the SL qZSI operates in CCM and ensures the demanded gain of the input voltage $\left(U_{D C 2}=490 \mathrm{~V}_{\text {peak }}\right.$, as expected $)$.

The simulated and experimental waveforms of the grid voltage and current $U_{\text {grid }}$ and $I_{\text {grid }}$ of the proposed interface converter at this operation point are presented in Fig. 13. It is seen that the grid side PWM inverter operates correctly thus ensuring the $230 \mathrm{VAC}_{\mathrm{rms}} 50 \mathrm{~Hz}$ grid voltage.

The second group of simulations and experiments was performed at the generator side DC link voltage of $250 \mathrm{~V}$. The power rating was $1250 \mathrm{~W}$. The shoot-through duty cycle of the SL qZSI was set to 0.17 to ensure necessary voltage boost at this operation point. Both DC link voltages and input current are shown in Fig.14, while the grid voltage and current in Fig.15. Experimental results clearly demonstrate the converter's ability to ensure the required grid voltage level at all operation modes of the interface converter.

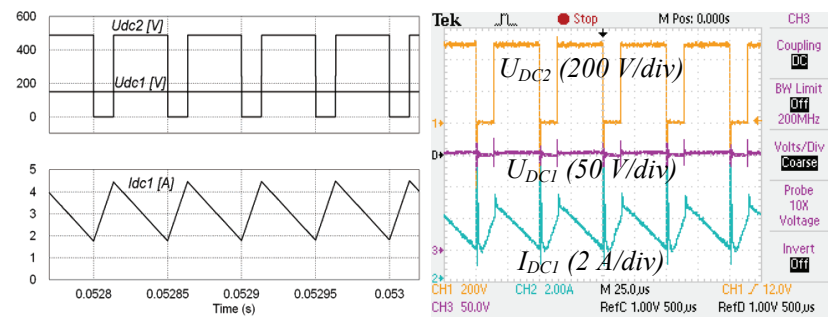

a)

b)

Fig. 12. Simulated (a) and experimental (b) waveforms of operating voltages and input current of the SL qZSI at $330 \mathrm{~W}$ 


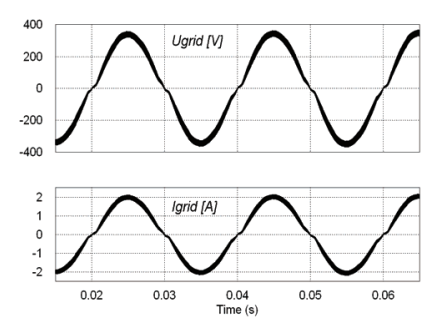

a)

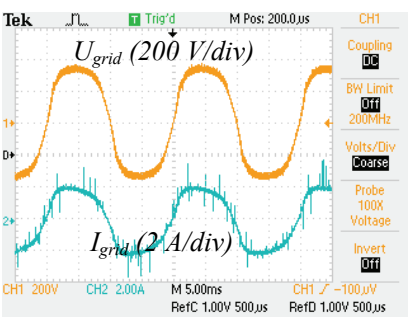

b)
Fig. 13. Simulated (a) and experimental (b) waveforms of the grid voltage and current at $330 \mathrm{~W}$

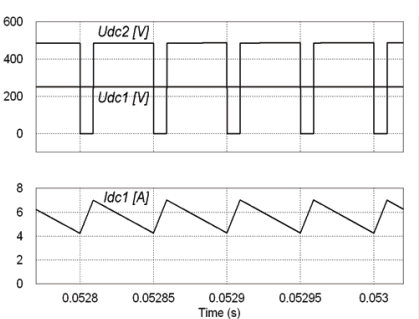

a)

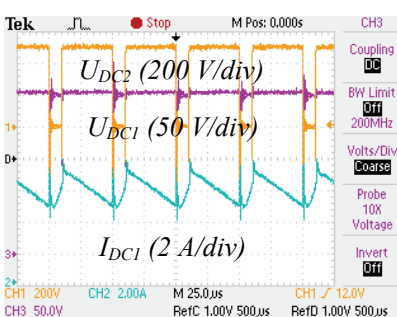

b)
Fig. 14. Simulated a) and experimental b) waveforms of qZSI voltages and current at $1250 \mathrm{~W}$ load

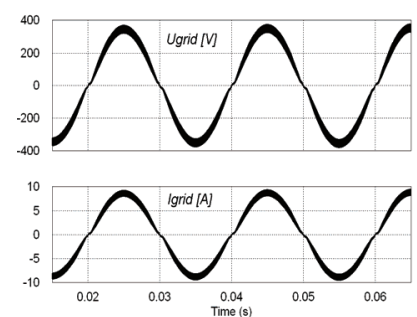

a)

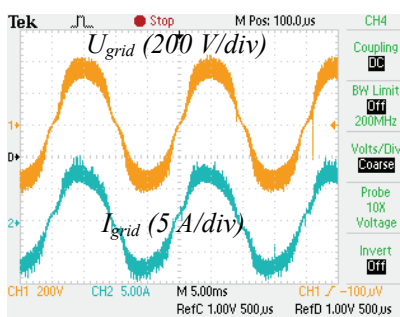

b)
Fig. 15. Simulated a) and experimental b) waveforms of SL qZSI output voltage and current at $1250 \mathrm{~W}$ load

\section{Conclusions}

This paper presents a new SL qZSI based back-toback converter for grid-connected PMSG based wind turbines. The general structure and operating principles of the proposed converter are discussed and general equations are given. To verify theoretical assumptions the $1.3 \mathrm{~kW}$ laboratory prototype of the proposed converter was elaborated and tested. The results of performance tests demonstrate the SL qZSI ability to ensure the required sinusoidal output voltage at all operation modes of PMSGbased WSVT.

The main advantage of the proposed converter is the enhanced output voltage regulation properties thanks to the new SL qZS network implemented.
The proposed topology could be implemented in the residential PMSG based wind turbines with power rating up to $15 \mathrm{~kW}$.

\section{Acknowledgements}

This research was supported by Estonian Ministry of Education and Research (Project SF0140016s11), Estonian Science Foundation (Grant ETF8538) and Estonian Archimedes Foundation (project "Doctoral school of energy and geotechnology II“" and DORA5).

\section{References}

1. Blinov A., Vinnikov D., Jalakas T. Loss Calculation Methods of Half-Bridge Square-Wave Inverters // Electronics and Electrical Engineering. - Kaunas: Technologija, 2011. - No. 7(113). - P. 9-14.

2. Bisenieks L., Vinnikov D., Galkin I. New converter for interfacing PMSG based small-scale wind turbine with residential power network // Compatibility and Power Electronics (CPE'2011), 2011. Unpublished.

3. Fujin Deng, Zhe Chen. Power control of permanent magnet generator based variable speed wind turbines // Proceedings of ICEMS'2009, 2009. - P. 1-6.

4. Li X., Bhat A. Multi-cell operation of a high-frequency isolated DC/AC converter for grid-connected wind generation applications // Proceedings of ICIIS'2009, 2009. P. 169-174.

5. Pathmanathan M., Tang C., Soong W.L., Ertugrul N. Comparison of power converters for small-scale wind turbine Operation // Proceedings of AUPEC'08, 2008. - P. 1-6.

6. Zhang S, Tseng K, Vilathgamuwa M., Nguyen D. Design of a Robust Grid Interface System for PMSG-based Wind Turbine Generators. // IEEE Transactions on Industrial Electronics, 2009. - No. 99. - P. 1-6.

7. Dehghan S. M., Mohamadian M., Varjani A. Y. A New Variable-Speed Wind Energy Conversion System Using Permanent-Magnet Synchronous Generator and Z-Source Inverter // IEEE Transactions on Energy Conversion, 2009. Vol. 24. - No. 3. - P.714-724.

8. Mittal R., Sandhu K. S., Jain D. K. Low voltage ridethrough of grid interfaced wind driven PMSG // ARPN Journal of Engineering and Applied Sciences, 2009 - P. 7383.

9. Vinnikov D., Roasto I., Zakis J., Strzelecki R. New Stepup DC/DC Converter for Fuel Cell Powered Distributed Generation Systems: Some Design Guidelines // Przeglad Elektrotechniczny - 2010. - No. 86. - P. 245-252.

L. Bisenieks, D. Vinnikov, S. Ott. Switched Inductor Quasi-Z-Source Based Back-to-Back Converter for Variable Speed Wind Turbines with PMSG // Electronics and Electrical Engineering. - Kaunas: Technologija, 2011. - No. 8(114). - P. 61-66.

This paper presents a new converter topology for interfacing a permanent magnet synchronous generator based variable speed wind turbine with a residential power network. Analysis of the converter topologies studied earlier shows that they are not well suited for PMSG with low output voltage. PMSG characteristics are discussed in order to formulate requirements for a power converter. A new topology of an interfacing converter is analyzed and simulation results of a lossless model are presented. Simulation results of the proposed converter prove that its utilization in wind power applications is beneficial. The results of performance tests demonstrate the SL qZSI ability to ensure the required sinusoidal output voltage at all operation modes of PMSG-based WSVT. Ill. 15, bibl. 9, tabl. 1 (in English; abstracts in English and Lithuanian).

L. Bisenieks, D. Vinnikov, S. Ott. Besikeičiančio induktyvumo keitiklio qZS taikymas kintamo greičio vėjo jėgainèse // Elektronika ir elektrotechnika. - Kaunas: Technologija, 2011. - Nr. 8(114). - P. 61-66.

Pateikiama nauja keitiklio topologija. Atlikus tyrimus nustatyta, kad esami keitikliai nèra tinkami. Ištirtos PMSG charakteristikos, ir jas apibendrinus iškelti nauji reikalavimai keitikliui. Pateikti modeliavimo rezultatai. Il. 15, bibl. 9, lent. 1 (anglų kalba; santraukos anglų ir lietuvių k.). 